講

座

\title{
附 本病原体の人体感染例
}

\section{佐 藤 多津 雄*}

この疾病は主として倸に登生し，急性ないし慢性の経 過を近る质染病ですり，その病原体估ウィルスである。 本邦に和いては, 昭和 5 〜 18年の間, 各地に大流行中散 発的発生が見ら机た。当時この疾病は家禽ペストと称さ れていれが, 中村稕治らの鶏体交叉免疫試験により，1 ギリスの DOYLE によって, ニューカッスル地区に招け る登生に際して分離された株は, 免疫学的に家禽ペスト と異るととが証明され，之の分離地名をとってニューカ ッスル病と称した疾病と, 同一のものであると同定され れ、しかしてての時代に和ける感染発症鵎は, ひな, 成 鶏を問わず，死亡率は恬とんぞ $100 \%$ 高率です⿹，か つ部检上消化器系統の器官, すなわち腺筋胃の出血, 腸 管の限局性の著明な出血, 藵死は擎死鵎の $70 \%$ に見 れ, とれが当時の野外発生時に和ける診断に, 重要な特 徵とされていた。との型のニューカッスル病は全欧州並 びに萝洋に広く存在していた。この高死亡率, 部検上の

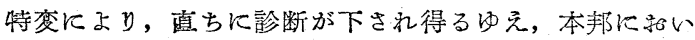

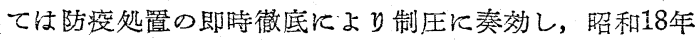
以降は発生が見られなくなった。しかるに昭和 26 年 1 月 飞至って呼吸器症状, 下峲, 神経症状を伴ら, 極めて緩 徐な病原性を示す榣疾患が，埼玉に扣いて発生してい るのが当試験場によって, 初めて検出され, かつ病原体 る分離され，それについて種々試験せる結果, 病原体は ウィルスにして, 前記のニューカッスル病病原体と, 交 叉免疫学的にまた血清学的に同一籍疇の疾病であるとと が川島秀雄らによって証明された。てのよらな鵎疾病 が，原因なくして突然本邦に発生したものではないす てに昭和11年頃, アメリカのカリフォルニヤに括いて, この緩徐な鶏疾病の発生が見られ, 昭和17年に至ってて れはニューカッスル病であるととが同定されている. 更 にその症状, 部检所見により，乙の型のものに肺媨炎型 (アメリカ型), 一方高死亡率々消化器系統に出血, 壞死 変状を伴ら型には, 罢腸炎型 (欧州型) といら名称が附 与されている。しかして散戦後に扣ける米軍の占領を, それに伴ら物質の搬入により，それに附随してアメリカ より本邦に病原体が入ったととは明らかな事実である。

昭和 26 年以来現在に至るまで每年発生を見ているの は, との肺脳炎型のニューカッスル病であり, 罢腸炎型 のものはまだ1例もこの間に発生を見ていない.以下と の肺脳炎型ニューカッスル病について述べて見ることと する。

1. 病原体の侵入部位 策験的にはいかなる部位から でも, 容易に健康䳕に感染発症さすことがでさるが, 野 外に㧺いては主として呼吸器(吸入), 消化器 (採食) を。 介乙て病原体は鵎体内に侵大する.

2. 感染の原因 本病原体は自然界の環境に対して抵 抗性が強いため, これに污染された物を無処置のままで

\footnotetext{
* 農林省家畜衛生試験場
}

放置する場合，特に温度の低い，日光光線の直射を受け ない場所，またはとのようなところに，污染器具などを 放置すると長く病原体が残って次回感染なたは伝播の誘 因となる，同一鶏舎内または楧内に和いては，本病に罹 った搯の排浛する下廁便, 分泌する日腔内粘液には多量 に病源体が含まれているゆえ，これらによって污染され た飼料，飲水，空気などを健康熖が摄取吸入した場合に 次々と感染が伝播する. 発病地に調查に行った際経験せ ることであるが，本病発生を留俰所へ届出前に病原体を 多量㑢む, 発症鶏体を肉用として売却されている。こ れらはある処理場 (多くは都市) に和いて調理され，そ の際骨, 被毛, 内臓, 組なぞが排亩され, この排亲物が 野菜渣と共に農村に豚の飼料としてか方ってきている. このような飼料を与えている養豚養䧟兼業家の鸴に, ま ず本病が発生し爾後附近の養鵎家へ人, 鶏, 器具の䔟動 に伴って, 漸次その周辺に本病が波及した例を今まで 3

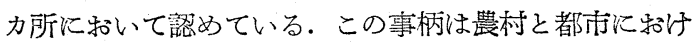
る，本病の雳循環を物語っている.すなわち本病原体の 保有鷄または污染されたものは, 器具, 資材などを閣わ ず一切が感染源となると見做してよい。

3. 症状 野外発生時また笑験的感染試験において も, 潜伏期間は 2 2 14日で平均 5〜6 日である.

症状は年令によって変化が認めらるるも, 通篗すれば 呼吸器系統, 消化器系統, 神経系統の諸器管が侵される ゆ觉，これらによる障害が現われてくる．かつ体温の上 笔 $\left(42.5^{\circ} \mathrm{C}\right.$ 以上)が顕㻎に見られる. 数日から数週令の 若ひなでは, 最初に見られる普通の症状は, 呼吸困難(開 口呼吸)，意気銷沈，昏迷状態となり，4〜5日後に頭 部の震璗, 脆弱, 脚麻㾝を現わす.症状を現わしてか

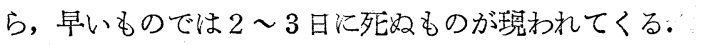
産卵彩をたは成鶏では呼吸症状が最初に見られ、これと 共に下浰便（緑色便に乳白粘稠液になった尿を混ずる） が見られるものが多い. 徉ってゼイゼイやガアガアとい 万䳛き声，時にキャッという奇声を発する声 (いずれす 気管内に粘液が多く分泌されてきたために起す声) が䏣 瞭に聞えてきて, $1 \sim 2$ 週間位継続する. 食欲不振, 元 気銢失, 被毛光沢なく, 特に肛門部の被毛は下痢便に て, 緑白色活染されているのが見られる. 間もなく脚 麻痺にて起立不能に至り, 整死するものが出てくる.こ のような症状を現わして数日後には, 頍頸部の神経症状 が現われ始める、すなわち斜賁, 頚部捻転, 口嘴上向な ど楀々な健康洔と異った状態が，鵎体を急に動かした

日獣会誌 7 (1954) 
時，または採食，飲水時などに特に発作的に䫒著涀ら れる．これは死に至るまで残る後遺症である.

4. 死亡率 睬化後上り 2 力月令以内では， $60 \sim 70 \%$ の死亡率を示する， 3 力月令以上では，5 20\%の低い 死亡率を示す. 死亡の直接原因は, 気管内滲出物による 窒息死の型を占めるものが多く見られる.

5. 産卵に対する影響 感染発症 $2 \sim 3$ 日の経過後, 急激に産畉率が低下し，ほとんぞ 0 の状態が $2 \sim 3$ 週間 継続する. 回復䳕群では $1 \sim 2$ 力月休産し, 以後漸次回 復して以前の率汇達するものが多い，但し換羽を伴う時 は更に休産が延長する。

6. 剖検所見 欧州型ニューカッスル病鶢に見られる ような, 腺・筋胃, 腸管の著明な出血, 壞死は, アメリ カ型肺脑炎ニューカッスル病には注とんぞ見られない が， 3 カ月令以下の若ひなには，まれに腺・筋胃に出圌 が認められる. 更に気管, 気管芰, 肺内に粘液の 㵔溜

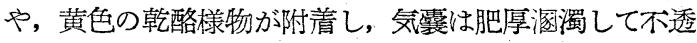
明である.消化管の変状は極めて軽度で, 腺胃が著明な カタールを示し白黄色粘液の附着を認めることあるも， 粘鄚のカタールる一般に非常に軽度で出血などは洼とん ぞない。十二指腸以下の腸粘膜に和いても軽い充出血を 認めるも, カタール変状が強く, ヂフテリー性出血性腸

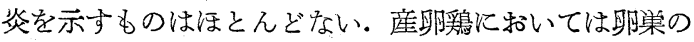

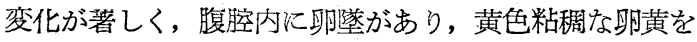
含み, 腹膜の肥厚が認められる. 卵盷は種々な形状を示

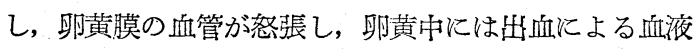

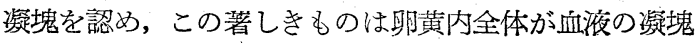
となり，血腫様卵を呈するものもある．更に不正形卵が しばしば見られる。これらの畉巣変化は急性，慢性例共 に見られ，産卵停止もこれに原因するものと思われる。

しかしながらこの卵巣の变状は，いわゆる鶏伝染性下莉 症, 伝染性気管支炎様舀の場合飞も見られるゆえ儿, 単 にこの躯巣の著しき変状の久では, 本病の特徴的変化と して診断し得ない，他の笑筫臟器では, 腎に括ける尿酸 塩の沈着により，灰褐色の䘰色溷濁した痛風様腎の像が 見られる。

7. 病原体の体内分市 本病感染鶏は血中はもち ん, 体内いたるところの諸臟器に病原体が分布し, 多く の場合発病後 2 週間以内は潘とんど病原体を排泄ずる。 回復䳕においては, 流血中に抗体が証明せられるに従っ て, 体内の臟器には病原体の証明ができなくなってく る.しかして回復䳕においても保毒者になったり，また は病原体を排泄する例のあることが認められている，更 そ産畉鵴においては，その畉款または卵内容中に病原体 を附着または含有する。回復䳕または産畉について，い か添ど経過したら病原体が完全に存在しなくなるかとい らことは, 限られた数の試験結果によって, 野外に和け る多数例の個々体についての判定は, 到底出来得ないと
ころである.

8. 他種いの感染 䳕以外飞七面鳥, アヒル, 鵟, 沜, ホロホロ鳥などより, 病原体の分離または抗体の存在に よって, 感染することが証明されている.これらのもの は感染しても極めて軽度な, または無症状の不顕性感染 の姿を呈するものが多い.このような家禽が本病伝播の 媒介者として，一役割を演ずることがある.

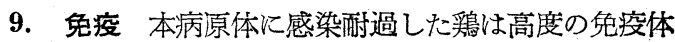
を有し， 9 カ月より 1 年半以上にわたって持続する.こ

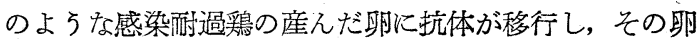
から睬化したひなは，睬化後28日以内その血中に抗体の 存在することが証明されているが，このような抗体を有 するひなは, 完全にすべて本病原体の侵入浜抗するも のではなく, 侵大病原体の毒力, 量などにより種々なる も若下は発症を示す。

10. 診断 いずれの伝染病に括いて子共通しているこ とであるが, ニューカッスル病は臨床上，剖検上他の䌔 疾病と類似している点が多いゆえに, 確定診断には, 病 原体の分離かまたは血清中に, その病原体に珓しての特 異的な抗体の存在するや否やが試みられねばならない。 推定的䛦断は類症鑑別の項を参照されたい。

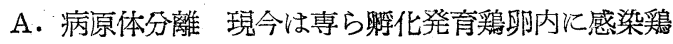
の材料を接種する方法によっている. 病原体が存在すれ ば接種後 $2 \sim 3$ 日で, 卵胎児は致死し, その卵内液を集 めたものに舀の血球を入れると該血球が濒集してくる (血球凝集反応と称する)ので, 病原体の存在することが 判る．また一方健康釉に接種して発症の有無にて試べる 場合もある。

B．血清中の抗体証明 この抗体証明の方法には，操 作の簡単にして，短時間に明確に判定のできる血球㠜集 抑制反応が広く笑施されている。すなわちニューカッス ル病病原体は舀血球を㠜集するが，感染耐過貌血清を入 れると凝集が起らなくなってくる。このような血清は血 球凝集抑制抗体を含しでいるとい5，この抗体が血球凝

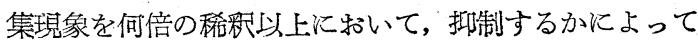
陰性，疑陽性を決定する．次に血清々病原体との中和試 験, これにほ相当の費用と, 既知の生きた病原体, 陽性, 陰性血清を必要とする．生きた病原体を $10,100,1000$ 倍と稀稂したものに，既知血清と可検血清を各々等量宛 混合，また対照として病原体のみのものを作り，一定の 温度で一定時間感作, 中和さしてから, 䁔化発育鵎卵に 接種し, 卵胎児の致死を算出して, 対照に比べて血清を 入れた方は何倍まで㽗胎児の致死が中和によって出た か, すなわち対照と血清混合列との卵胎児致死差沈よっ て判定する。この他核補体結合阻止反応るまた特異的な もので兴施される.この確定㟝断は設㣁のある, 熟練し

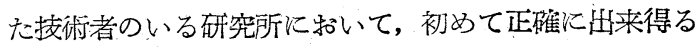
ものである、な和この種，診断を位頼する場合には，発 
生状洗, 臨床所見, 剖検所見を詳細に記入して, 病原体 分離材料としては, 出来得れば発应中の生きている鵎 を，哀隔の地であればそれを殺して脑，肺，気管，膵葴 を採集し50\%のグリセリン水中に浸積して送附する。で きるだけ無菌的取扱いが望ましいが，若干污染されても よい.このよ5になすと共に発症 4 〜 5 日後の 鵎 血液 $2 \mathrm{cc}$ 宛を, 発症群の約 1 割位の羽数を採血して後送する ことが特に望ましい.これは鵎体から必ずしも毎常, 病 原体が分離できるとは限らない，そのような場合には後 送の血清を用いて抗体証明による本病の診断ができるか らである.附加事項としてこのような依頼の際には,必ず 最寄の家畜保健所または県㕂に連絡して笑施されたい。

11. 類症鑑别すべて診断または鑑別は，そのよって 起る原因体を証明する, 確定診断によって最終的判別は なされるも，その原因体の侵す生体の反応を，個々体に よって観察する時には個体差, 侵入する病原体の量など によって若干の差異を示し, 專門家といえども鑑別は容 易ではない。しかしながら群全体を観察した場合には， 相当度その病原体に対して侵された生体側の反応(症状) に共通性が認められる. 以下この概念によって, ニュー カッスル病と臨床上, 剖検上最も紛らわしい, 屯た現在 発生を見ている疾病について, 推定診断の要点を挙げて みることとする，それには伝染性気管支炎様疾病といわ ゆる伝染性下浰症である・ニューカッスル病については 症状の項に記述した如く, 呼吸器症状と下㾋, 更に神経 症状が発生群中に明らかに所見される。

伝染性気管支炎様疾病に扮いては呼吸器症状が主体を なす，産畉鶏においては時に下莉便が見られるも，ひ な, 中雛群に打いては認め難いし，また神経症状は全く 認められない，いわゆる伝染性下浰症に和いては，水瀉 様便後 $1 \sim 2$ 日にして, ニューカッスル病と同様な緑色 下痢便を認めるも, 呼吸器症状, 神経症状は認められ ず，食膟を顕著に認める．触診するに陵囊は硬固にして 承分に欠くる感がある. 死亡率の点より観るに，ひなに 和けるニニーカッスル病は60〜70\%であるが，伝染性気 管艾炎様疾病では極めて低く，5 10\%以下が普通であ る. いわゆる伝染性下痛症のひなに和计る発生は今のと ころ不明である.

12. 防疫 本病に似た症状を示す病䳕を発見したる時 は, まずその舀群の移動，売却，殺処分を止めるように して直ちに関係庁所へ連絡して指示を受けるよ5にする ことである. しかる後の殺処分に当っては，特に被毛の 散乱を防ぐこと, 䳕舎の消毒について特に天井など上部

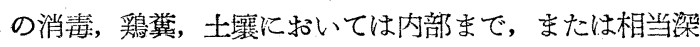
部まで消毒剤が達するようにする.この際飼育に用いた 器具器材も忘れてはならない.な和䳕舎の消毒は, 2 〜 3 回徹底的に実施する. 再度健康鷄を導入するような場 合には，導大前今一度类施することが望ましい。被毛，

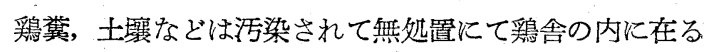
時は, 9 カ月より 1 年半にわたって本病原体が生きて

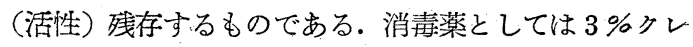
ゾール石ヶン液, $2 \%$ アルリ消毒䠼がよい，睬卵器は ホルマリン消毒が適当である. 鵎卵懞の消毒には $2 \%$. 蒲性曹達液または $2 \%$ クレゾール石ヶン液に，2〜5分 浸積する。

13. 予防 本病には治療薬はないが，予防には極めて 有效な予防液があり, 筋肉内注射によって危疫性を附与. せしめ得る，回復冊鵎より卵黄を通じて，そのひなに受 働免疫を得せしめて，これを䂆方の手段にせんとする人 も特ったが，すでに記述した如く，この種試験結果を検 討すると, 受動免疫を有する期間は 4 週間以内で, しか. もとの間に本病原体に暴露されると再感染発症を来して いる例多きにつき，この種の試みはなさるべきではない と考えられる.

\section{ニューカッスル病病原体の人体感染 について}

そもそも本病原体の人体感染を報告した最初は, 昭和 18 年オーストラリヤに拉いてであり, その後イスラェ ル, ハンガリー,アメリカ, カナダ，西ドイッに和いて その報告例が見られる.からと報告例数も漸次多くな ってきている.これらの報告はいずれも病原体の分離を 基としてなされて特り，抗体証明による場合は非特異的 反応また病原体分離例と同一症状を示すも, 人間に感染 した場合は，抗体上算が多くの例に検出されず困難を来 している.これら諸報告を基として, 感染した人々の職 業を見ると家禽疾病研究所員 (兴験者, 飼育者, 屍体処, 理者, 器具洗深者, 感染鵎卵資料の乾懆作業彷事者) の, 例が多く, 感染鷄の解剖に従事した獣医師, 鶏肉加工場 員, 感染䳕肉料理人, 養䳕農夫, 家离商, 養鵎専業者で. ある.これらの人々は作業中污染した手指にての擦眼, 污染物のはね返り，傷口よりの活染などによって発病し ている. 症状 : 結膜炎が大多数例に見られ片側眼または 両眼が侵される.すなわち眼刺激痛, 㾕癌感, 流涙, 結 膜また暉膜の潮紅, 腫脹, 浮腫, 差明が現わるるも角膜

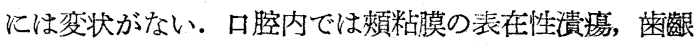
粘膜の充血, 扁桃腺炎, 咽堠頭粘膜の充血腫脹, 耳介前 淋巴結節の腫大, 鼻腔内出物の産出增加, 頭痛, 不快 感などであり，体温の上昇は顕著に認められない。潜伏 期間18〜24時間であると，その発病原因より推定されて いる.

治療としては硼酸水の洗眼，オーレオマイシン油剤の 擦入が試みられたるも，特に效果ありとは判定されてい ない. 経過は比較的良好で無処理で $4 \sim 7$ 日で核とんど 軽快し，ある患者は仕事に従事し続けた。細菌などに污 染されると若干回愎が遅延する。病原体の分離は，発病 
後 $3 \sim 6$ 日の間にとの洗眼液や垂液，鼻腔内济出物，血 液, 尿からも分離されて, ニューカッスル病病原体と同 定されている。亦た結膜上皮細胞中に封入体様物を検出 せりとの報告もある。

筆者らが啋の二ューカッ・スル病の発生地区調査に訪れ てみると, 戦後副業養鵎が盛んになってきて扣り，かつ 発生を見ているのは專業者よりも副業者の家に多く，発 症を関俰所へ届出前,すでに一部自家用に供したり，また 他に肉用として転売して了っている. 更に年々の発生現 況に鑑み，本邦に和いても人体感染の存在が推定され， 昭和 26 年肺脳炎型ニューカッスル病が鵎に発生した時 飞，人体感染することがあるとの警告が発せられ来った が，遂に本邦に物いても，本年春の細菌学会に特いて某 少年院児童の含嗽液中より, 三重医大によって病原体が
分離され, 二ューカッスル病病原体, 肺脳炎型と一致す ることが報告された。このような結膜炎を示さずして， 呼吸器系統より分離された例はカナダに和ける報告例と 類似している. ニューカッスル病病原体の感染は人獣共 通伝染病の特徵を有して物り，人から人への伝染，また 人から家离への感染はまだ知られていないが，公衆衛生 上，本病が鶏に発生した際に，その処置を第一番に担当 するわれわれ獣医師は，原因估が人体感染する可能性を 念頭瞋き自己並びにその発生地区の人々にも注意を払 ら共に本病についての㤵蒙の学をとる必要がある。

(本稿は防疫の第一線を担当される獣医師の方へとし て起草したものなるゆえ，関保交献記載を省略します）

稿を終るに臨夕人体感染例の附加の必要性を述へられ た小林場長に敬意を表すると共に，御校閲下されを石井 部長に深甚なる感謝の意を表します。

\section{昭和 28 年次の獣医師に関する統計}

獣医師法第21条の規定により獣医師から提出された届出書に関する集計（昭和28年12月31日現在）が 農林省畜産局衛生課に扎いてとりまとめられたので，参考まで揭載する。

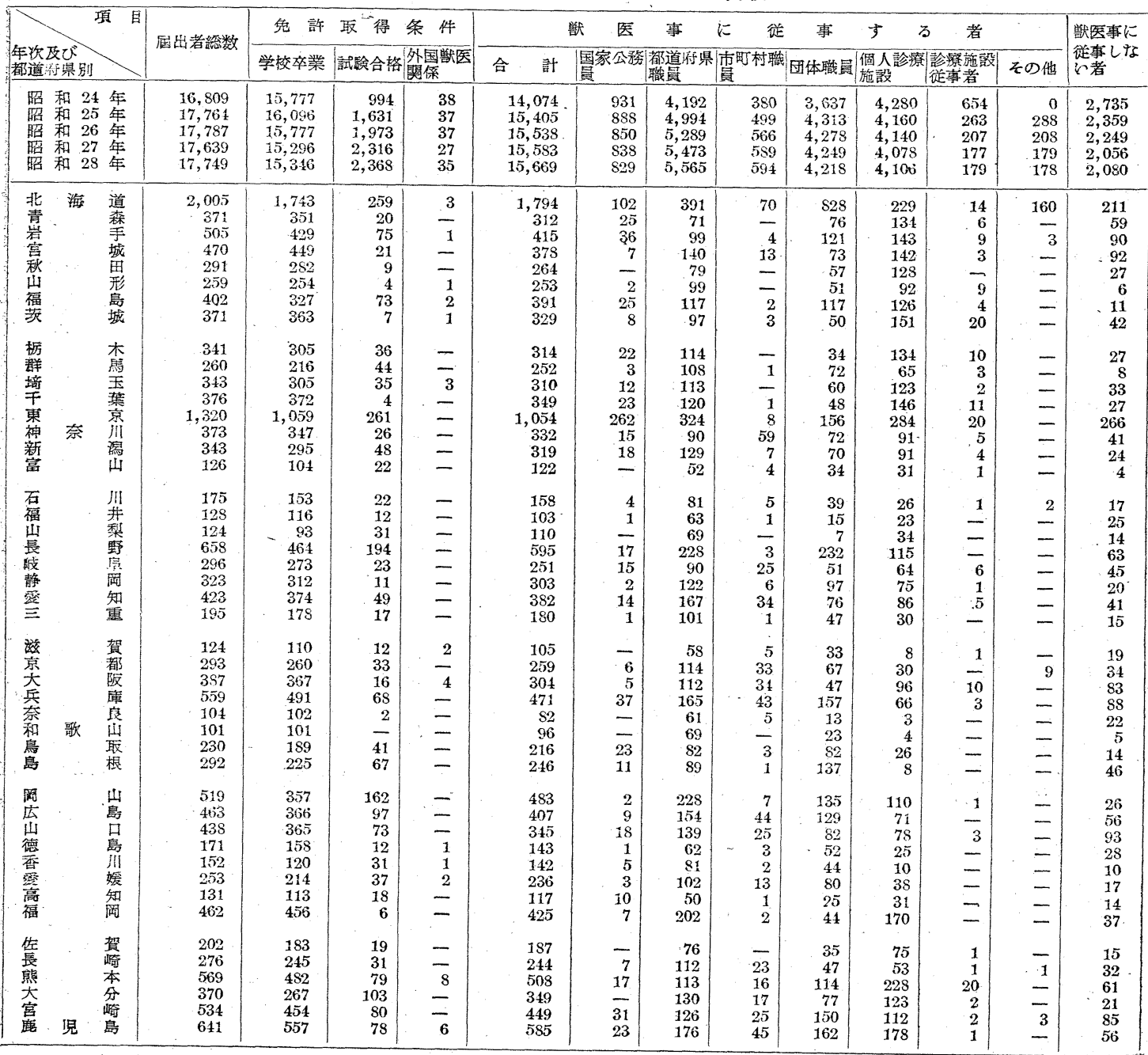

